\title{
The kinase inhibitor D11 induces caspase- mediated cell death in cancer cells resistant to chemotherapeutic treatment
}

\author{
Barbara Guerra ${ }^{*}$, Mette Fischer ${ }^{1}$, Susanne Schaefer ${ }^{1}$ and Olaf-Georg Issinger ${ }^{2}$
}

\begin{abstract}
Background: Multi-drug resistance and predisposition to metastasize are major clinical problems in cancer treatment. Malignant primary brain tumor and pancreatic cancer are two well-known examples of malignant tumors resistant to conventional therapies where aberrant EGFR-mediated and NF-KB signal transduction pathways are likely to play an important role. We have recently identified 1,3-Dichloro-6-[(E)-((4-methoxyphenyl)imino)methyl] diben-zo(b,d) furan-2,7-diol (D11) as a potent and selective inhibitor of CK2 a serine/threonine protein kinase that modulates the aforementioned signaling cascades.

Methods: Human cancer cell lines (glioblastoma and pancreatic adenocarcinoma) resistant to conventional chemotherapeutic agents were incubated with increasing concentrations of D11 for variable amounts of time. Cell viability, cell death and effects on major signal transduction pathways deregulated in cancer cells were analyzed by ELISA, FACS and Western blot-based assays, respectively. Moreover, effects on cell migration and in cell protein-protein association were investigated by wound-healing and in situ proximity ligation assays, respectively.
\end{abstract}

Results: We show here, that D11 treatment leads to i) significant caspase-mediated apoptotic cell death, ii) downregulation of EGFR expression and iii) inhibition of NF-kB transcriptional activity. Furthermore, cell exposure to D11 results in impaired cell migration and correlates with reduced expression of the ion co-transporter and cell volume regulator $\mathrm{Na}^{+}-\mathrm{K}^{+}-2 \mathrm{Cl}-(\mathrm{NKCC} 1)$.

Conclusions: Data reported here underline the therapeutic potential of D11 with respect to certain types of cancer that carry aberrant intracellular signaling cascades and/or exhibit sustained cell migration and suggest a new therapeutic strategy against chemotherapy resistance.

Keywords: Kinase inhibitors, EGFR, NF-KB, NKCC1, ROCK, Apoptosis, Glioblastoma, Pancreatic adenocarcinoma

\section{Background}

Cancer is a disease characterized by genomic alterations that confer a selective growth advantage to cancer cells. In recent years, large-scale multi-dimensional analysis of clinical data has provided a detailed map of the major molecular alterations occurring during cancer development and led to two important observations: i) tumors originating from the same type of tissue or organ display significant differences with respect to genomic alterations and ii) tumors with different origin bear common

\footnotetext{
* Correspondence: bag@bmb.sdu.dk

'Department of Biochemistry and Molecular Biology, University of Southern Denmark, Odense, Denmark

Full list of author information is available at the end of the article
}

genetic alterations that result in enhanced survival, proliferation and drug resistance $[1,2]$. The epidermal growth factor receptor (EGFR) signaling is a major regulator of cell survival and motility (reviewed in [3]). Overexpression or mutation of EGFR is often responsible for tumor resistance to both chemotherapy and radiotherapy [4-9]. Resistance of tumors overexpressing EGFR is linked to aberrant phosphoinositide 3-kinase (PI3K)/AKT pathway, a key signal transduction system that links multiple receptor classes and oncogenes [10,11]. Recent cancer genomic studies have revealed that multiple components of the PI3K pathway are frequently targeted by germline or somatic mutations [12-14]. In this respect, the tumor suppressor phosphatase and tensin homolog (PTEN) and AKT 
are found frequently mutated in cancer ([15] and reviewed in [16]). The nuclear factor- $\mathrm{B}$ (NF-кB) signaling pathway is often constitutively activated in cancer due to mutations in the genes coding for NF- $\mathrm{kB}$ isoforms or in those coding for proteins (e.g. I $\mathrm{KB} \alpha$ ) that control NF- $\mathrm{kB}$ activity $[4,6,11]$.

We have recently identified 1,3-Dichloro-6-[(E)-((4methoxyphenyl)imino)methyl] diben-zo(b,d) furan-2,7diol (referred to as D11) as a novel potent and selective inhibitor of protein kinase CK2 from a screening of 1600 compounds of the Diversity Set III from the DTP program of the $\mathrm{NCI} / \mathrm{NIH}$ [17]. Protein kinase CK2 is a constitutively active serine/threonine protein kinase whose expression and activity has been found elevated in all so far investigated tumors and highly proliferating tissues (reviewed in $[18,19]$ ). Interestingly, CK2 modulates the PI3K/AKT signaling cascade by targeting AKT and PTEN for phosphorylation. Moreover, it regulates the NF-kB pathway by promoting ІкB degradation and NF-кB phosphorylation that results in enhanced DNA binding and transcriptional activity of the latter [20-23].

In this study, we have analyzed the potency and biochemical mechanisms of cell death induction of D11 on glioblastoma and pancreatic adenocarcinoma cells that are characterized by aberrant EGFR/PI3K and NF-кB signaling pathways and resistance towards radio- and chemotherapy [24-27]. Results reported here show that D11 exerts potent anti-tumor effects warranting further in vivo studies for validating its efficacy against multi-drug resistant cancer cells.

\section{Materials and methods}

\section{Cell culture and treatments}

The human glioblastoma cell lines M059K and U-87 MG and the human pancreatic adenocarcinoma cell line MIA PaCa-2 were purchased from the American Type Culture Collection (ATCC, Rockville, MD, USA) and cultivated at $37{ }^{\circ} \mathrm{C}$ under a $5 \% \mathrm{CO}_{2}$ atmosphere in Dulbecco's modified Eagle's medium (DMEM, Invitrogen, Taastrup, Denmark) supplemented with $10 \%$ fetal bovine serum (FBS, Biochrom AG, Berlin, Germany). MIA $\mathrm{PaCa}-2$ cells were additionally cultivated in the presence of $2.5 \%$ horse serum (Biochrom AG). Cells were treated with D11 (DTP, NIH/NCI, Rockville, MD, USA), IGF-1 (Calbiochem, Nottingham, UK) and TNF $\alpha$ (R\&D Systems, Abingdon, UK) as indicated in the figure legends. Cell transfection was carried out with Lipofectamine 3000 reagent (Life Technologies, Naerum, Denmark) according to the manufacturer's guidelines and a plasmid carrying the coding region for farnesylated AKT devoid of the PH domain prepared according to [28]. The correct sequence and orientation were verified by DNA sequencing. Neocarzinostatin (NCS) was kindly provided by Dr. Hiroshi Maeda, Kumamoto University, Japan.

\section{Determination of cell viability}

D11-mediated cytotoxicity was determined by the WST-1 viability assay (Roche, Hvidovre, Denmark). Viability was quantified in a microtiter plate reader (VersaMax ELISA, Molecular Devices, Sunnyvale, CA, USA) after adding the WST-1 reagent to the cells according to the manufacturer's guidelines.

\section{Flow cytometry analysis}

Cell cycle analysis and determination of cell death was determined as previously described [29]. The analysis was carried out on a FACS-Calibur flow cytometer (BD Biosciences, San Jose, CA, USA). Acquired data were processed by Cell Quest Pro Analysis software (BD Biosciences). For each measurement, 10,000 events were analyzed.

\section{Preparation of whole cell lysate, Western blot analysis and antibodies}

Cells were harvested and further processed for Western blot analysis as described in $[26,30]$. The following primary antibodies were employed in the study: mouse monoclonal anti-AKT, mouse monoclonal anti-poly (ADPribose)polymerase (PARP), mouse monoclonal anti-RAFT1/FRAP/mTOR (all from BD Biosciences); mouse monoclonal anti-caspase 8 , mouse monoclonal anti-caspase 9, rabbit monoclonal anti-caspase 3 , rabbit polyclonal anti-PTEN, rabbit polyclonal anti-phosphoPTEN (S380/T382,383), rabbit monoclonal anti-phosphoAKT (S473), rabbit polyclonal anti-phospho-AKT (T308), rabbit polyclonal anti-phospho-mTOR (S2481), rabbit monoclonal anti-Raptor, rabbit polyclonal anti-phosphoRaptor (S792), rabbit monoclonal anti-Tuberin/TSC2, rabbit polyclonal anti-phospho-Tuberin/TSC2 (S1387), rabbit polyclonal anti-phospho-Tuberin/TSC2 (T1462), mouse monoclonal anti-phospho-p70S6K (T389), rabbit polyclonal anti-phospho-AMPK $\alpha$ (T172), rabbit polyclonal anti-AMPK $\alpha$, rabbit monoclonal anti-NF-kB/p65/ RelA, rabbit monoclonal anti-NF-kB/p65/RelA (S536), rabbit monoclonal anti-phospho-IKK $\alpha / \beta \quad(\mathrm{S} 176,180)$, rabbit polyclonal anti-IKK $\alpha$, rabbit polyclonal anti-IKK $\beta$, rabbit monoclonal anti-phospho-IKB $\alpha$ (S32), mouse monoclonal anti-IkB $\alpha$, rabbit monoclonal anti-NKCC1 (all from Cell Signaling Technology); mouse monoclonal anti$\beta$-actin (Sigma-Aldrich); rabbit polyclonal anti-EGFR, rabbit polyclonal anti-p70S6K, rabbit polyclonal antiHSP90, mouse monoclonal anti-CDC37 (all from Santa Cruz Biotechnology, Heidelberg, Germany); rabbit polyclonal anti-phospho-NKCC1 (T212,217), rabbit polyclonal anti-AKT1 (both from Millipore, Billerica, MA, USA) and 
rabbit polyclonal anti-phospho-NF-kB p65 (S529, Abcam, Cambridge, MA, USA).

\section{Immunostaining and in situ proximity ligation assay} Cells grown on coverslips were fixed with $4 \%$ paraformaldehyde for $15 \mathrm{~min}$, permeabilized with $0.1 \%$ Na-citrate, $0.1 \%$ Triton X-100, pH 7 for 5 min and, where indicated, counterstained with 4',6'-diamidino-2-penylindole (DAPI, Sigma-Aldrich, Brøndby, Denmark). Actin filaments where visualized by Alexa Fluor 488 phalloidin staining (Invitrogen) for $20 \mathrm{~min}$ at room temperature according to the manufacturer's recommendations. Localization of NF- $\mathrm{kB}$ was performed by incubating the cells with rabbit monoclonal anti-NF-kB/p65/RelA antibody (Cell Signaling Technology, Herlev, Denmark) at $4{ }^{\circ} \mathrm{C}$ overnight followed by labeling with biotinylated swine anti-rabbit immunoglobulin (Dako, Glostrup, Denmark) for $1 \mathrm{~h}$ at room temperature and Alexa Fluor 488-conjugated streptavidin (Life Technologies) for $30 \mathrm{~min}$ at room temperature. Cells were analyzed for HSP90-CDC37 interaction by in situ proximity ligation assay (PLA, Olink Biosciences, Uppsala, Sweden) according to the manufacturer's recommendations. The number of positive signals was determined using Blobfinder software (http://www.cb.uu.se/ amin/BlobFinder). Cells were analyzed on a Leica DMRBE microscope equipped with a DFC 420C camera and Leica Application Suite V 3.3.0 software (Leica Microsystem, Wetzler, Germany).

\section{Transcription factor assay}

The transcriptional activity of NF- $\mathrm{kB}$ was measured applying the TransAM assay system kit (Active Motif, Carlsbad, CA, USA) following the manufacturer's recommendations. Quantification was performed with a VersaMax ELISA microplate reader (Molecular Devices).

\section{ROCK kinase assay}

ROCK activity was measured using the ROCK1/2 activity assay kit (Cell Biolabs, Inc., San Diego, CA, USA). After treatment, cells were harvested, washed in ice-cold PBS and lysed. Kinase assay was performed according to the manufacturer's recommendations. Measurements were obtained with a VersaMax ELISA microplate reader (Molecular Devices) using $450 \mathrm{~nm}$ as the primary wavelength.

\section{Wound-healing assay}

Cells were cultured in $60 \mathrm{~mm}$ Petri dishes until confluent. Subsequently, straight scratches were made with a p200 pipet tip across the Petri dishes simulating a wound [31]. Pictures were taken at different intervals as indicated in the figure legends using phase contrast and the $5 \mathrm{x}$ objective on a DMIRB microscope (Leica Microsystem). Unhealed areas were quantified using the ImageJ64 software.

\section{Statistical and densitometric analysis}

The statistical significance of differences between means of two groups was determined by the two-tailed $t$-test (Student's $t$-test). The levels of significance are indicated in the figure legends.

\section{Results \\ Cytotoxic effects of D11 in cancer cell lines}

Human glioblastoma cells (M059K) and human pancreatic adenocarcinoma cells (MIA PaCa-2) were tested for in vitro sensitivity to D11 (Fig. 1a). The inhibitory concentration $\left(\mathrm{IC}_{50}\right)$ was achieved with $40 \mu \mathrm{M}$ D11 after $48 \mathrm{~h}$ of incubation in M059K cells while for MIA PaCa2 cells, similar effects were achieved with $60 \mu \mathrm{M}$ D11 after $72 \mathrm{~h}$ of incubation with respect to control experiments. Additionally, analysis of U-87 MG glioblastoma cells showed that treatment with $25 \mu \mathrm{M}$ D11 for $24 \mathrm{~h}$ resulted in $50 \%$ decrease in viable cells (Additional file 1: Figure S1).

Next, cell cycle analysis was investigated by flow cytometry (Fig. 1b and Additional file 2: Figure S2). Cells were treated with various amounts of drug for $24 \mathrm{~h}$ (M059K) and $48 \mathrm{~h}$ (MIA PaCa-2), respectively. With respect to control experiments, significant differences in the percentage of cells with reduced DNA levels (i.e. sub-G1) were observed with $50 \mu \mathrm{M}$ D11 (M059K) and $80 \mu \mathrm{M}$ D11 (MIA PaCa-2) treatment, respectively. Western blot analysis (Fig. 2a) indicated that $50 \mu \mathrm{M}$ D11 induces cleavage of full-length PARP in M059K cells after $24 \mathrm{~h}$ incubation time while significant PARP cleavage was observed in MIA PaCa-2 cells when treated with 60 and $80 \mu \mathrm{M}$ D11 for $48 \mathrm{~h}$, respectively. Analysis of cleavage-mediated caspase activation revealed that both the intrinsic and extrinsic apoptotic pathways [32] are involved in D11-induced cell death. In order to determine whether treatment with D11 can sensitize cancer cells towards conventional antitumor drugs, we incubated M059K with the radiomimetic drug neocarzinostatin (NCS) alone or in combination with D11. Combined treatment affected the viability (Additional file 3: Figure S3a) and resulted in enhanced apoptotic cell death (Additional file 3: Figure S3b) suggesting that D11 partially sensitizes glioblastoma cells to NCS.

Rho-associated kinase ROCK1 is a serine/threonine kinase that has been identified as a caspase- 3 target involved in the blebbing process observed in apoptosis $[33,34]$. Hence, we determined whether D11 treatment results in enhanced ROCK kinase activity. Significant increase in the phosphorylation of myosin phosphatase target subunit 1 (MYPT1) was observed as compared to control experiments, demonstrating that cell exposure to D11 leads to activation of ROCK kinase in both cell types (Fig. 2b). It has been shown that cells committed to detachment as observed in the activation of cell death, 


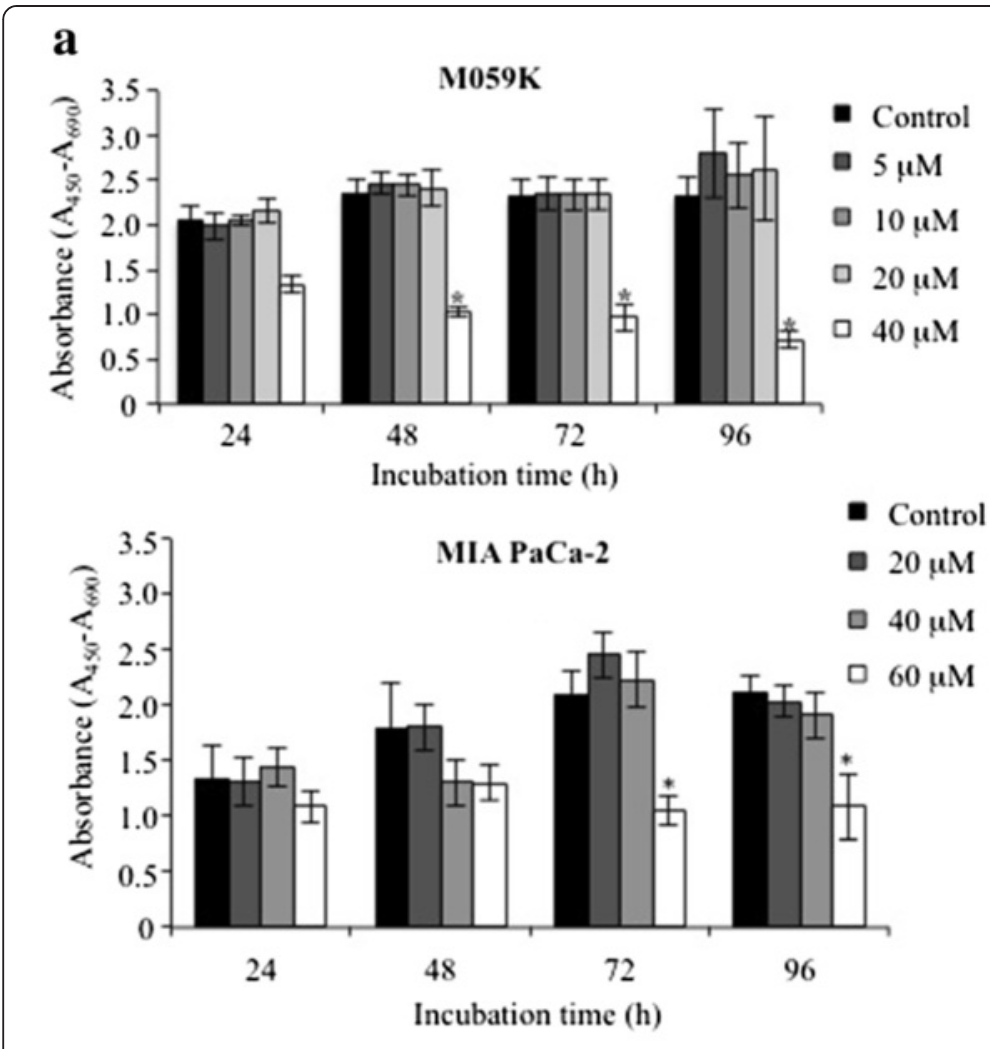

b
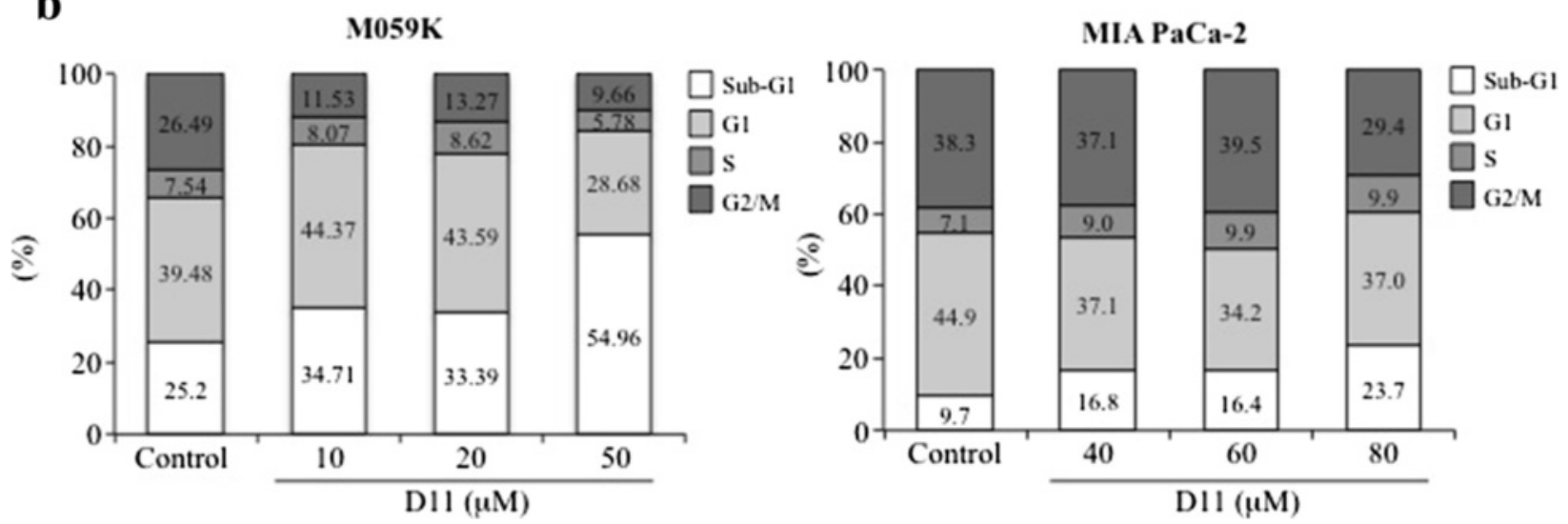

Fig. 1 Anti-proliferative effects of D11 in human cancer cell lines. a M059K and MIA PaCa-2 cell lines were treated with increasing concentrations of D11 for a variable amount of time, respectively. Control experiment refers to cells treated with vehicle (0.1\% DMSO). The proportion of viable cells was determined by WST-1 assay and expressed in arbitrary units as a difference in absorbance measured at 450 nm and 690 nm (reference) wavelengths, respectively (mean $+/$ - standard deviation, $N=6$ ). Asterisks denote statistical significant differences between control and D1 1-treated cells for the corresponding time points, ${ }^{*}, P<0.0001$. b Flow cytometry analysis of cells treated with $0.1 \%$ DMSO (Control) and increasing concentrations of D11 for $24 \mathrm{~h}$ (M059K) and $48 \mathrm{~h}$ (MIA PaCa-2), respectively. The amount of cells in the various phases of the cell cycle is indicated in percentage. Experiments were repeated three times obtaining similar results. Data from one representative experiment are shown

often exhibit disruption of central stress fibers and a contractile ring containing filamentous actin (F-actin) at the cell periphery [35]. Studies performed by employing mouse embryonic fibroblasts showed that cytoskeleton reorganization is dependent on the expression of active ROCK1 [36, 37]. Hence, we analyzed D11-mediated effects on actin filaments dynamics by staining cells with phalloidin [38]. D11 treatment resulted in actin cytoskeleton remodeling in both cell lines characterized by reduction of central stress fibers and formation of a ring of filaments at the cell periphery (Fig. 2c). Overall, results show that D11 exposure induces apoptotic cell death at varying treatment conditions depending on the type of cells, and that glioblastoma cells are more 


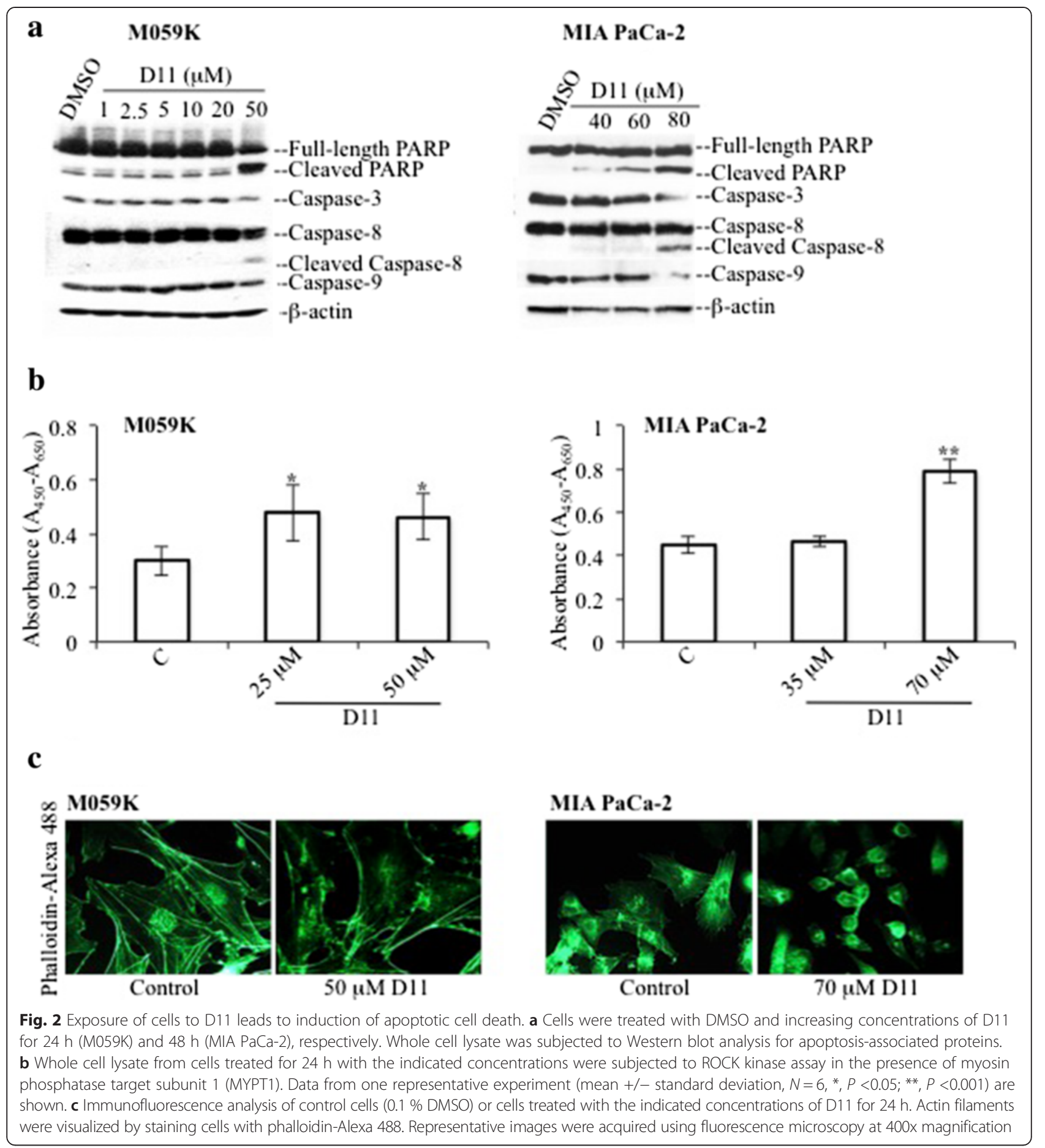

sensitive to the cytotoxic effects of D11 than pancreatic cancer cells.

\section{D11 treatment suppresses pro-survival signaling}

pathways

\section{PI3K/AKT pathway}

Components of the PI3K/AKT pathway were analyzed following short exposure to D11. Results presented in Fig. 3a show that D11 treatment led to a significant decrease of EGFR, mTOR, Raptor and Tuberin/TSC2 protein expression. This correlated with low phosphorylation levels of the corresponding proteins with respect to control experiments. Additionally, D11 treatment resulted in inhibition of AKT and p70S6K kinase activity although a less pronounced decrease in their expression levels was observed. PTEN status was investigated only in MIA PaCa-2 cells. 
$\mathbf{a}$

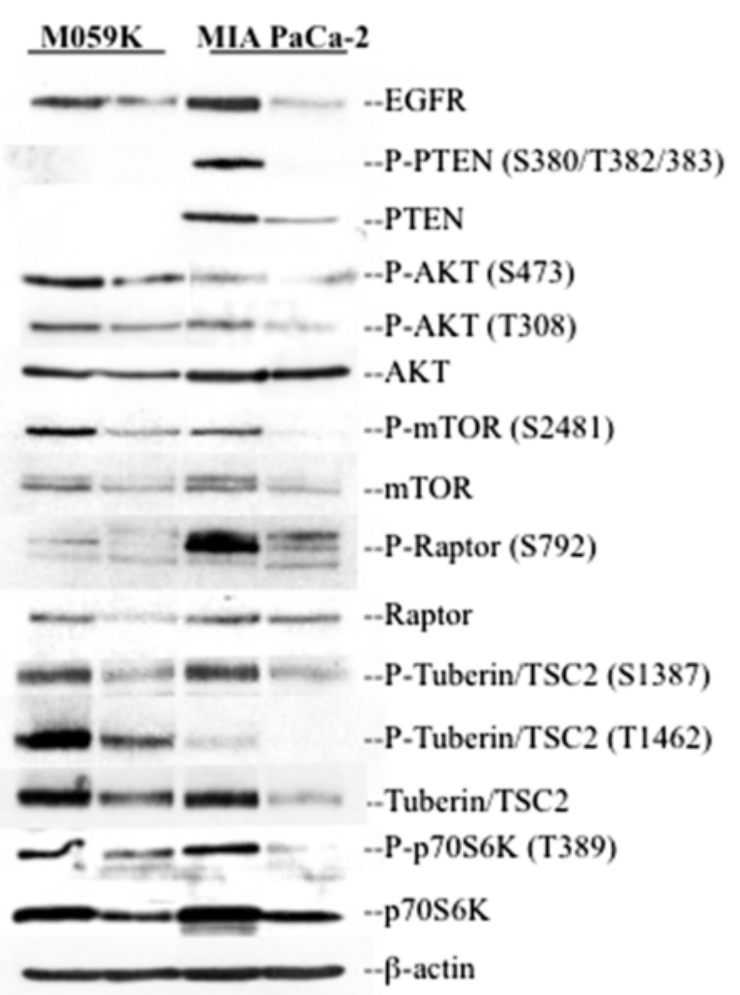

$\mathrm{D} 11(\mu \mathrm{M})-50 \quad-70$

b
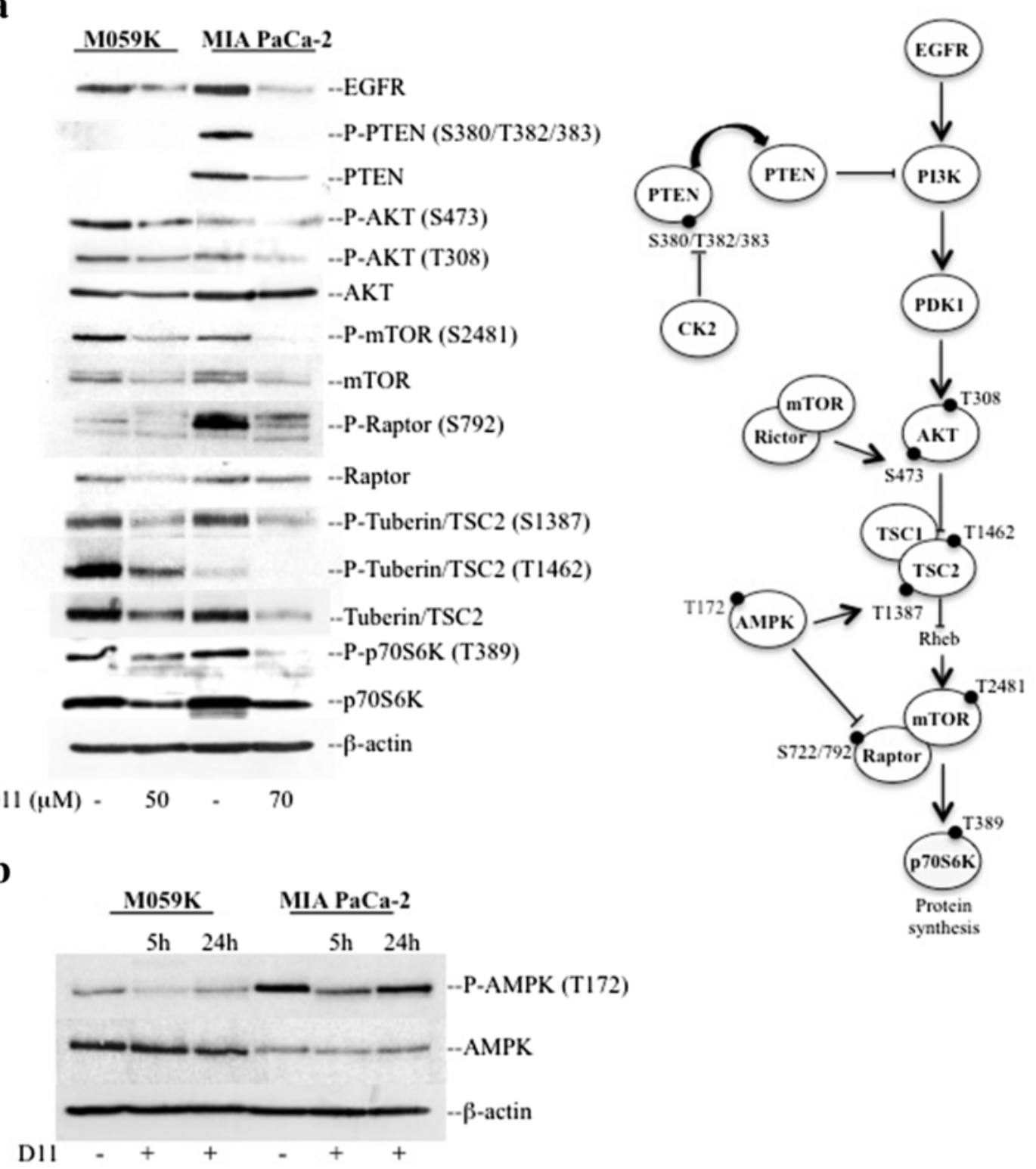

C
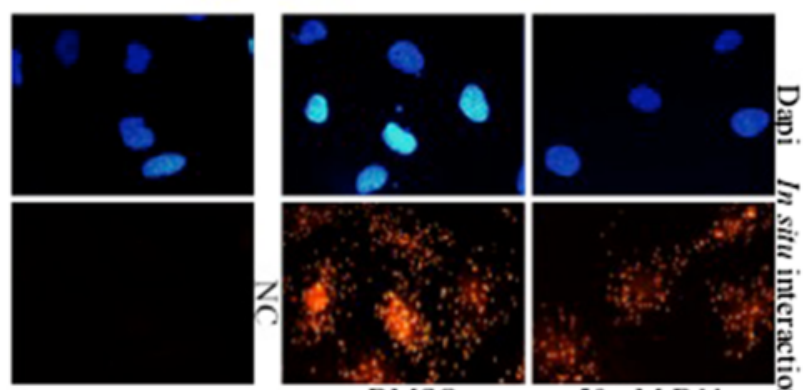

DMSO
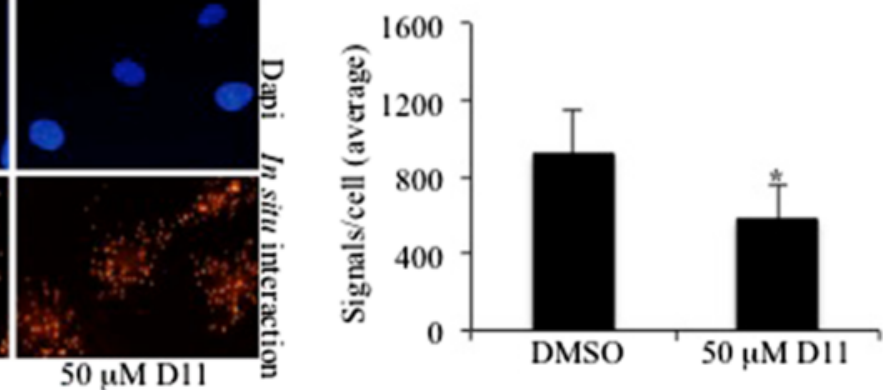

Fig. 3 (See legend on next page.) 
(See figure on previous page.)

Fig. 3 Analysis of the PI3K pathway in cells treated with D11. a Whole cell lysates from the indicated cell lines were subjected to Western blot analysis. Expression and/or phosphorylation of the indicated proteins were analyzed after $5 \mathrm{~h}$ incubation with D11. Control experiments (-) refer to cells incubated with vehicle (0.1\% DMSO). b Cells were treated with vehicle (-) or $50 \mu M(M 059 K)$ and $70 \mu M(M I A$ PaCa-2) D11, respectively, for the indicated times. Whole cell lysates were subjected to Western blot analysis of phosphorylated AMPK and AMPK protein. $\beta$-actin detection was used as a control for equal loading. c Association between HSP90 and CDC37 was revealed in M059K by in situ proximity ligation assay (PLA). NC refers to untreated cells subjected to PLA where one of the primary antibodies was omitted. Determination of the number of signals per cell as distinct red fluorescence spots indicative of HSP90-CDC37 proximity, was performed by computer-assisted image analysis as described in the Materials and methods. Nuclei were visualized by DAPI staining (blue fluorescence emission). Experiments were repeated at least three times obtaining similar results. The figure includes a schematic representation of the EGFR/PI3K signaling network in mammalian cells $\left({ }^{*}, P<0.05\right)$

According to Sonkin et al., M059K cells have a G-M PTEN status assigned to cell lines with homozygous nonsense, frame shift, known loss of function missense mutation or dominant negative mutation of a specific tumor suppressor gene [39]. The analysis revealed that D11 treatment leads to decreased PTEN expression and phosphorylation levels.

AMP-activated protein kinase (AMPK) is a nutrient sensor responsible for cellular energy homeostasis (reviewed in [40]). AMPK exerts dual regulatory effects on the PI3K pathway by targeting Tuberin/TSC2, an inhibitor of mTOR [41], and the TORC1 scaffold protein Raptor [42] for phosphorylation. Short exposure to D11 led to significant loss of AMPK kinase activity, which was partially recovered after $24 \mathrm{~h}$ of incubation time (Fig. 3b).

The chaperon protein HSP90 (heat shock protein 90) promotes folding, trafficking and stability of more than 200 client proteins including ErbB2, EGFR, Raf, MEK, FAK, PTEN, AKT, Raptor and mTOR [43-46]. Chaperones' function is dependent on the presence of cochaperone proteins and co-activators [47]. CK2-dependent phosphorylation of the co-chaperone CDC37, has been shown to be necessary for HSP90-CDC37 heterocomplex stabilization with client protein kinases (reviewed in [48]). As treatment with D11 resulted in down-regulation of HSP90 client proteins, we analyzed the association between HSP90 and CDC37 by in situ proximity ligation assay. As shown in Fig. 3c, cell exposure to D11 resulted in significant decrease in signal intensity with respect to control cells suggesting that the observed decrease in expression of components of the PI3K signaling pathway may be due to destabilization of HSP90-CDC37 heterocomplex.

\section{NF-KB pathway}

NF- $\kappa B$ comprises a family of proteins existing as homoor heterodimers whose aberrant expression and/or activity have been associated with various types of solid tumors (reviewed in [49]). Within the canonical activation pathway, the NF-kB signaling is controlled by the tumor necrosis factor receptor leading to activation of $\mathrm{I} \kappa \mathrm{B}$

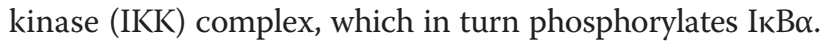

It follows $I \kappa B \alpha$ degradation and activation of $N F-\kappa B$ (reviewed in [50]). D11 treatment in combination with TNF $\alpha$ led to decreased phosphorylation of NF- $\mathrm{kB} / \mathrm{p} 65$ at S536 and S529 amino acid residues as well as the upstream IKK $\alpha / \beta$ at $S 176 / 180$. Interestingly, D11 treatment almost completely reversed $\mathrm{I} \kappa \mathrm{B} \alpha$ degradation induced by TNF $\alpha$ suggesting impaired TNF $\alpha$-mediated activation of the NF- $\mathrm{BB}$ pathway (Fig. $4 \mathrm{a}$ and Additional file 4: Figure S4). NF-кB activation downstream of EGFRdependent signaling is regulated by mechanisms involving directly AKT and the TORC2 (Rictor-mTOR) complex, respectively [51-53]. AKT functions through IKK to promote the phosphorylation and transactivation potential of NF- $k B$ [54]. Moreover, it has been shown that the AKTdependent TORC1 (Raptor-mTOR)/IKK interaction stimulates IKK activity which results in the phosphorylation of I $\mathrm{B} \alpha$ and activation of NF- $\mathrm{B}$ [55]. We analyzed whether overexpression of constitutively active AKT reversed D11mediated inhibition of NF- $\mathrm{kB}$ in cells treated with TNF $\alpha$. As shown in Fig. 4b, the expression of constitutively active $\mathrm{AKT}$ (farn-AKT) was unable to reverse NF- $\mathrm{BB}$ inhibition as the levels of IKK $\beta$-mediated phosphorylation of NF- $\mathrm{KB}$ at S536 as well as the CK2-mediated phosphorylation of S529 were essentially the same in cells transfected with empty vector or a vector expressing farn-AKT. As D11 is not a direct inhibitor of AKT, mTOR, IKK $\alpha / \beta[17,33,34,56]$, results reported above suggest that D11 treatment inhibits the NF-kB-dependent signaling by targeting molecule(s) other than the aforementioned proteins. Next, we analyzed whether D11 affects NF- $\mathrm{kB}$ migration and transcriptional activity induced by TNF $\alpha$. Exposure of cells to TNF $\alpha$ for 10 min promptly resulted in NF- $\mathrm{kB}$ nuclear localization in both cell lines (Fig. 5a). However, additional treatment with D11 inhibited significantly TNF $\alpha$-induced translocation of NF- $\mathrm{kB}$ in MIA PaCa-2 cells and only marginally in the case of M059K cells. To further support these results, we analyzed effects of D11 on the transcriptional activity of NF- $\mathrm{kB}$ induced by TNF $\alpha$. D11 treatment significantly inhibited the transcriptional activity of NF- $\mathrm{kB}$ in MIA PaCa-2 and U-87 MG cells (Fig. 5b). However, consistent with results reported in Fig. 5a, a modest but significant inhibition was observed in the case of M059K cells. 


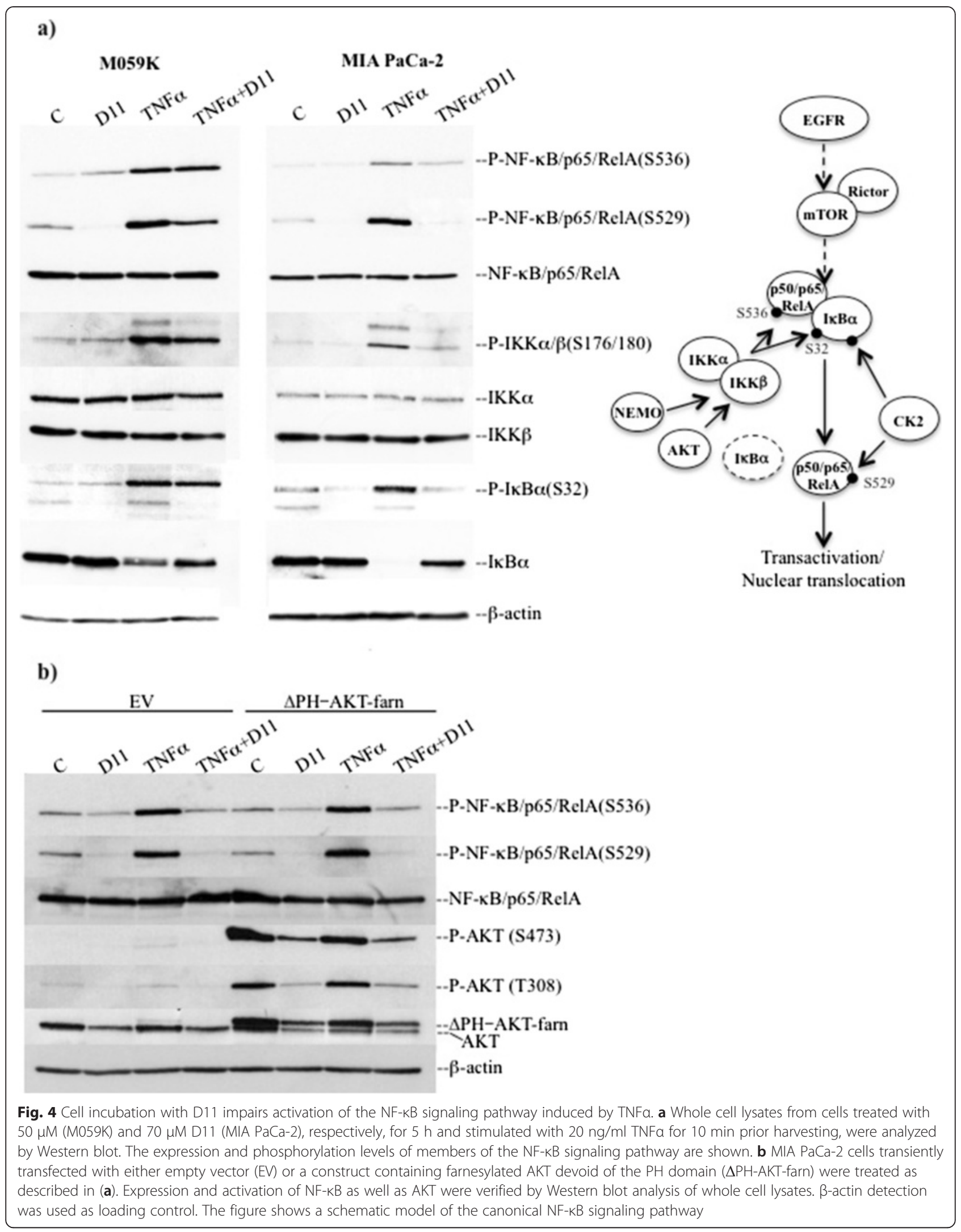


$\mathbf{a}$

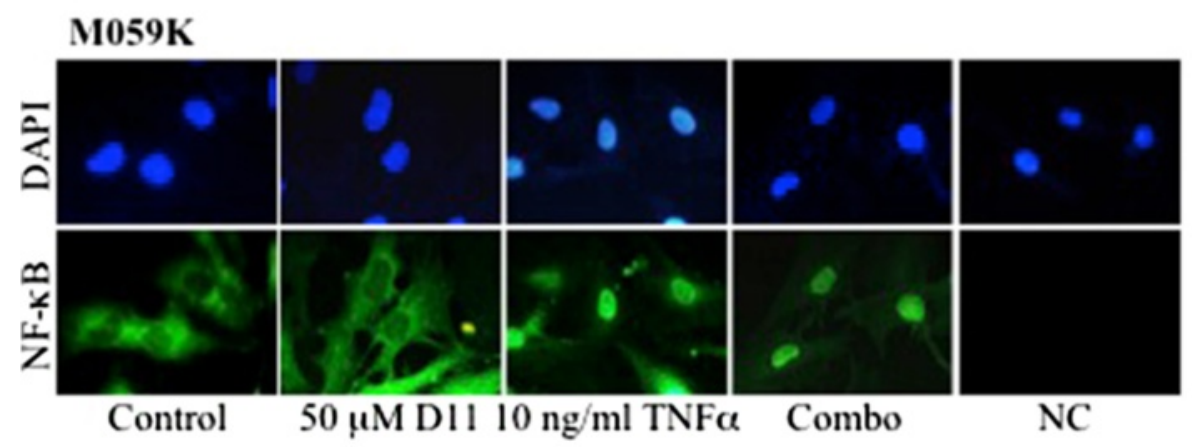

MIA PaCa-2

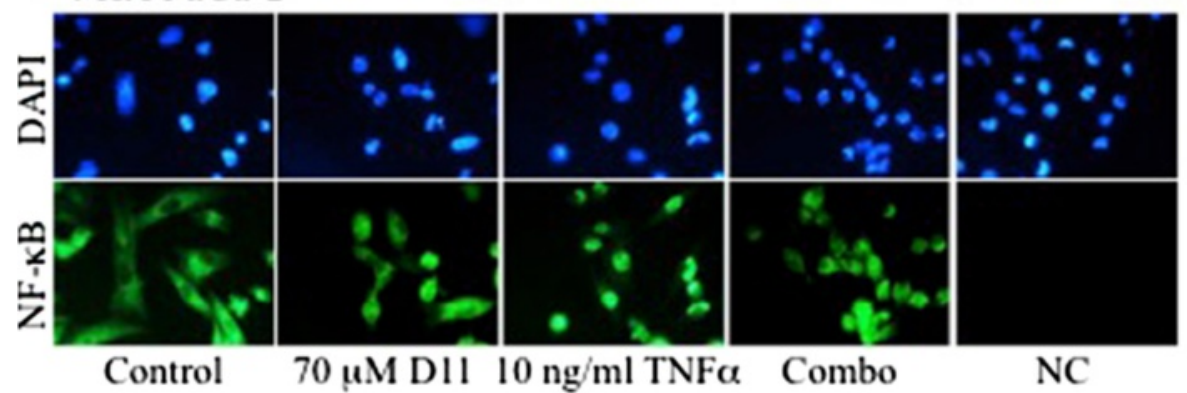

b

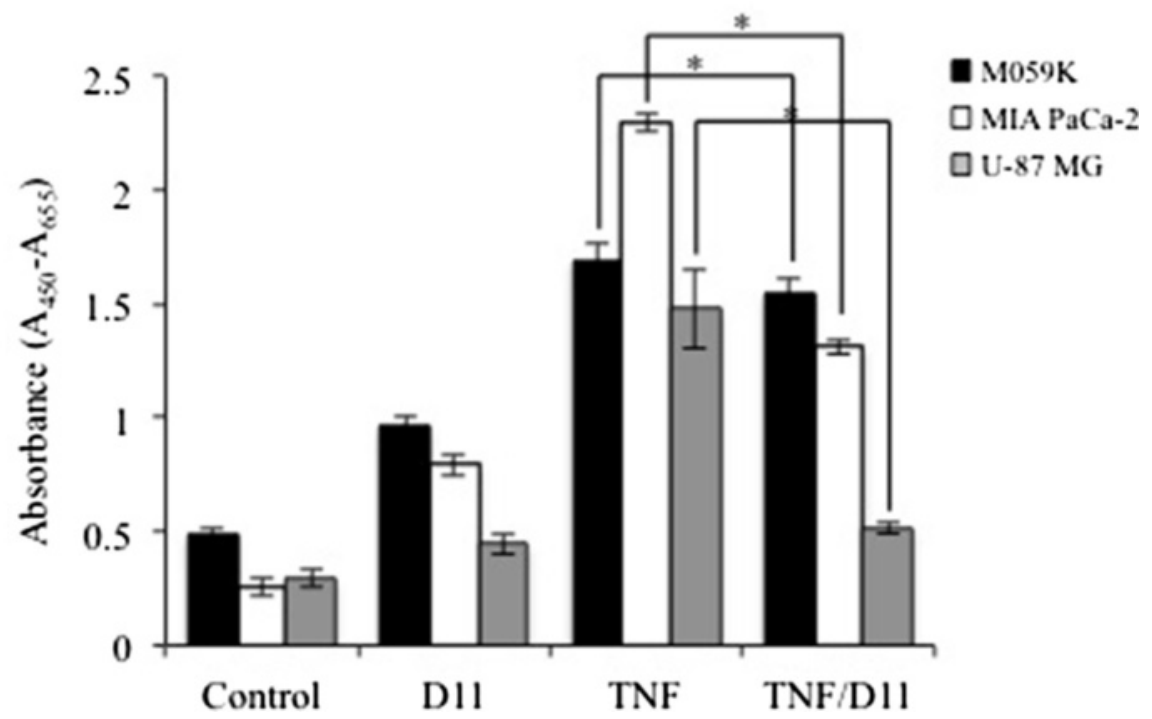

Fig. 5 D11-mediated effects on the transcriptional activity of NF-KB. a Cells were treated as described in Fig. 4 and Additional file 4: Figure S4. Subcellular localization of NF-KB was detected by immunofluorescence staining of cells with rabbit monoclonal anti-NF-kB antibody (green fluorescence, Alexa Fluor 488). Nuclei were visualized by DAPI staining. NC, negative control refers to cells stained with biotinylated secondary antibody and Alexa Fluor 488 streptavidin, only. Original magnification: 400x. b NF-kB transcriptional activity was determined as described in Materials and methods. The indicated cell lines were treated as described in Fig. 4. Asterisks denote statistical significant differences in TNFa-induced NF-KB activity in the absence or presence of D11 $(N=6, *, P<0.05)$. Experiments were repeated at least three times obtaining similar results 


\section{Cell incubation with D11 impairs cell migration and correlates with down-regulation of the $\mathrm{Na}^{+}-\mathrm{K}^{+}-2 \mathrm{Cl}^{-}$ co-transporter (NKCC1)}

Stimulation of EGFR controls migration through activation of the PI3K/AKT signaling cascade (reviewed in [36, 37, 57-59]). Interestingly, AKT has been shown to control cell motility through phosphorylation and activation of WNK kinases (With No K-lysine), which regulate the ion co-transporter NKCC1 a modulator of migration in glioma cells $[17,57,60-63]$. As treatment of cells with D11 resulted in decreased EGFR expression levels, we assessed whether this correlated with decreased cell migration. A wound-healing assay was carried out measuring cell-unwounded areas after varying incubation times with D11 according to the speed of cell migration. Results reported in Fig. 6a show that the presence of D11 significantly impaired the ability of both cell types to migrate. In the case of M059K cells, treatment with $50 \mu \mathrm{M}$ D11 led to about $27 \%$ decrease in the wounded area $16 \mathrm{~h}$ post-wounding. In control experiments, the wounded area decreased about $79 \%$. Control MIA PaCa-2 cells decreased the wounded area $65 \%$ at $36 \mathrm{~h}$ post-wounding while treatment with $70 \mu \mathrm{M} \mathrm{D} 11$ for $36 \mathrm{~h}$ led to approx. $52 \%$ increase in the wounded area suggesting impaired migration and, additionally, cell death induction. Next, NKCC1 phosphorylation levels were determined in cells left untreated or exposed to D11, IGF-1 or a combination of both, respectively. Results in Fig. 6b show that D11 treatment led to decreased phosphorylation of NKCC1 at T212/217, the major activating site in NKCC1 $[17,58,64]$, while EGFR activation by the pro-migratory IGF- $1[60,62,65,66]$ did not reverse effects induced by the presence of D11. However, analysis of NKCC1 expression indicated that D11 treatment leads to significant down-regulation of NKCC1 protein expression levels.

\section{Discussion}

EGFR gene amplification and mutation occur with high frequency in glioma (40-63\%) and pancreatic cancer (30-50\%). NF-kB, typically the p50-RelA/p65 heterodimer, is frequently activated in the aforementioned types of cancer resulting in enhanced cell proliferation and suppression of apoptosis. Two common mechanisms appear to contribute to NF- $\mathrm{KB}$ activation: i) deletion of the NFKBIA gene which encodes IкB $\alpha$ and ii) EGFR amplification. Given the importance of the EGFR and NF- $k B$ signaling in the control of cell proliferation, survival and motility, substantial evidence suggests that these pathways may be useful targets for treatment.

In this study, we have tested the ability of a small molecule compound, D11, previously identified through a large screening of a small molecule compound library, to induce cell death in glioblastoma and pancreatic cancer cells and explored effects induced on the aforementioned signaling pathways. We show that D11 treatment results in caspase-dependent activation of cell death, which correlates with increased activity of ROCK kinase. This is in line with previous data showing that caspase 3-cleaved ROCK1, phosphorylates myosin light chains that is a necessary event for the formation of dynamic membrane protrusions consistently observed in apoptosis [17, 33, 34, 56, 67]. Analysis of the actin cytoskeleton revealed actin filaments remodeling following D11 treatment characterized by the formation of a cortical ring of actin filaments at the cell periphery accompanied by the disappearance of central stress fibers (Fig. 2c). Surma et al., demonstrated that ROCK1 and ROCK2 play different roles in the regulation of stress fiber dynamics, ROCK1 being responsible for the disruption of central stress fibers in doxorubicin-treated cells $[36,37,57]$. Similarly, data reported here suggest that actin cytoskeleton rearrangement induced by D11 is mediated by ROCK1 activation.

Treatment with D11 led to inhibition of the EGFR/ PI3K signaling cascade. Protein expression analysis indicated that one of the reported effects was a significant down-regulation of HSP90-client proteins such as EGFR, PTEN, mTOR, Raptor and Tuberin/TSC2. D11 has been shown to be an effective inhibitor of protein kinase CK2 [17]. CK2 targets CDC37 for phosphorylation contributing to the stabilization of the HSP90-CDC37 heterocomplex and recruitment of client proteins. In situ proximity ligation-based analysis revealed attenuation of HSP90CDC37 interaction in cells treated with D11 suggesting proteasome-mediated destabilization and degradation of client proteins.

We evaluated effects mediated by D11 on the expression and activity levels of AMPK. The striking result that emerged from this analysis was the finding that short exposure to the compound leads to inhibition of AMPK although a partial recovery occurs after $24 \mathrm{~h}$ treatment (Fig. 3b). Defective AMPK activation has been shown in some cancer cell types suggesting AMPK stimulation as a novel therapeutic approach for cancer [58]. Paradoxically, we detected a basal activity level of AMPK in both brain and pancreatic cancer cells suggesting that active AMPK is essential for sustaining proliferation of these cell lines. In support of our findings, recent studies have shown that human glioblastoma cells, astrocytes and prostate cancer cells carry activated AMPK that is required to maintain cancer cell proliferation [60,62]. Altogether, these data indicate that the use of activators or inhibitors of AMPK as a therapeutic approach in tumor cells has to be carefully evaluated according to the biology of cancer cells.

The canonical NF-kB pathway was affected by D11 treatment. Data reported here show that D11 does reduce the TNF $\alpha$-stimulated transcriptional activity of NF- $\mathrm{kB}$ and 


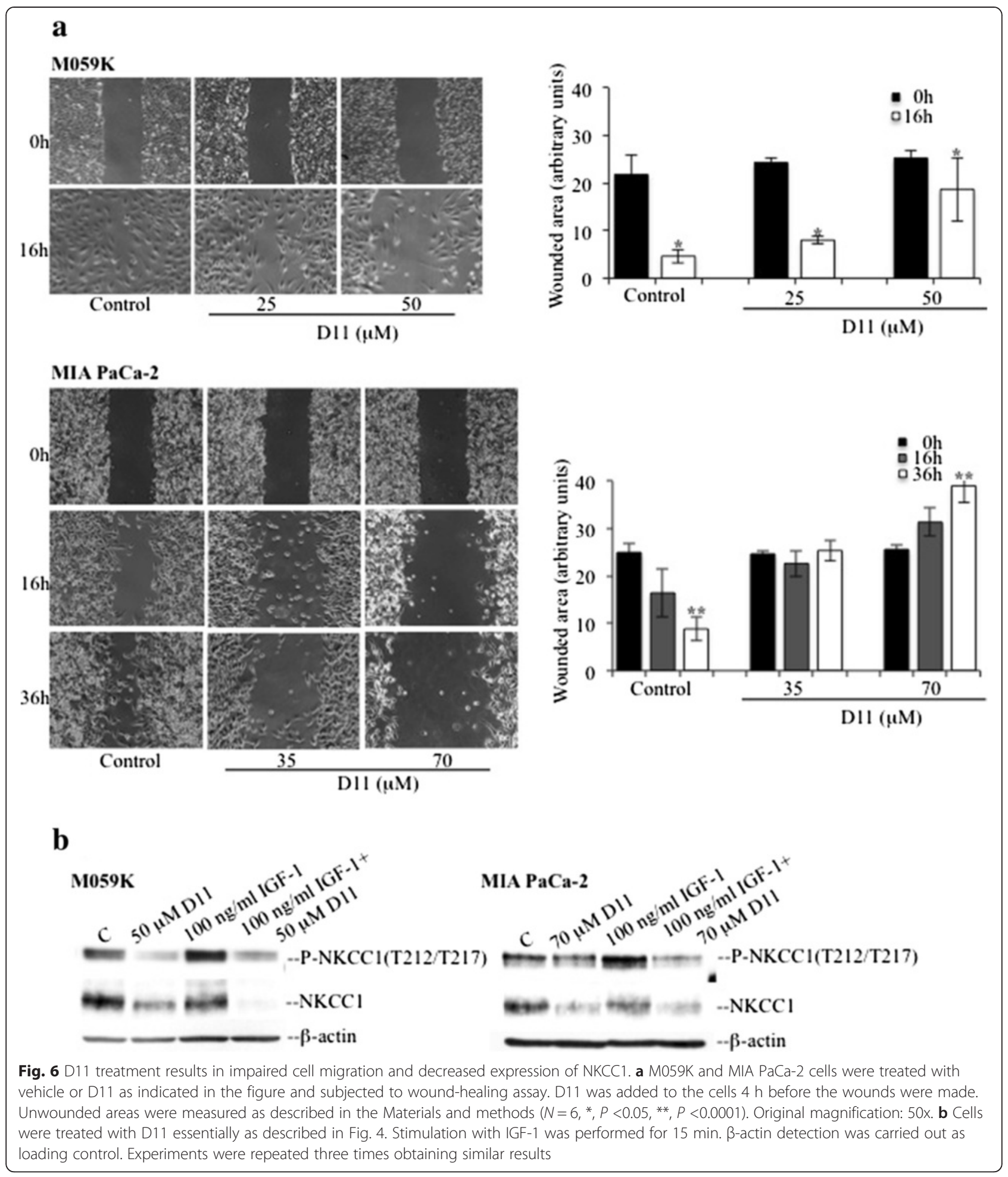

the extent of inhibition depends on the cell type. As D11 is not a direct inhibitor of IKK $\alpha / \beta$ [17], analysis of components of the aforementioned pathway suggests that inhibition of NF- $\mathrm{kB}$ results from D11-mediated targeting of EGFR, CK2 and, possibly, NEMO (IKK $\gamma)$. Moreover, it cannot be excluded that the HSP90-CDC37 heterocomplex might contribute to the regulation of $\mathrm{NF}-\mathrm{KB}$ as these proteins are part of the IKK complex and required for TNF $\alpha$-induced IKK activation (reviewed in [65]).

Compelling evidence has underlined the importance of the EGFR and NF- $\mathrm{kB}$ pathways in the regulation of tumor 
cell migration and invasion, the latter by regulating the expression of matrix metalloproteinases [67]. We found that D11 treatment significantly impairs migration of glioblastoma and pancreatic cancer cells that correlated with decreased expression levels of NKCC1 co-transporter. This is consistent with results reported in previous studies underlining the role of NKCC1 in the modulation of glioblastoma cell volume and motility [57]. NKCC1 has been shown to be an HSP90 interacting protein suggesting that decreased expression of the co-transporter might result from disruption of the HSP90-CDC37 heterocomplex and subsequent destabilization of NKCC1 client protein $[15,68]$.

Our group recently reported the identification of another protein kinase CK2 inhibitor, E9, showing cytotoxic effects on human hepatoma (HepG-2) and pancreatic carcinoma (Panc-1) cell lines with corresponding $\mathrm{IC}_{50}$ values of 19 and $30 \mu \mathrm{M}$, respectively, [69]. In the future, as one cannot exclude variability in cytotoxicity with different cultured cell lines, it will be interesting to compare effects induced by E9 and D11, respectively, with the cell lines employed in this study.

\section{Conclusions}

Overall, we report evidence that D11 treatment induces cell death and inhibits signaling pathways deregulated in brain and pancreatic cancer cells, notably, the EGFR and NF- $\mathrm{KB}$ signaling cascades. Exposure to D11 leads to: i) down-regulation of EGFR expression levels, which may represent a clear advantage for the treatment of certain types of cancers carrying aberrant expression of this growth factor receptor and ii) inhibition of cell motility particularly important in the case of highly invasive cancer cells $[16,70]$. Data reported here underline the therapeutic potential of this compound warranting further evaluation with respect to multi-drug resistant cancer cells.

\section{Additional files}

Additional file 1: Figure S1. Viability analysis of U-87 MG cells. Cells were treated with variable concentrations of D11 for the indicated times. The proportion of viable cells is expressed in arbitrary units as a difference in absorbance measured at $450 \mathrm{~nm}$ and $690 \mathrm{~nm}$ (reference) wavelengths, respectively. Control cells were incubated with vehicle (0.1\% DMSO). Asterisks denote statistical significant differences between control, $25 \mu \mathrm{M}$ and $50 \mu \mathrm{M}$ D11-treated cells for each time point, respectively, ( $\left.N=6,{ }^{*}, P<0.0001\right)$. (JPEG $30 \mathrm{~kb}$ )

Additional file 2: Figure S2. FACS analysis of M059K and Mia PaCA-2 cells. Histogram representation of the Flow cytometry analysis of cells treated as described in Fig. 1b. Quantification is shown in Fig. 1b. (JPEG $61 \mathrm{~kb}$ )

Additional file 3: Figure S3. Effect of D11 on NCS-induced cytotoxicity. (a) M059K cells were treated with D11 and NCS as indicated in the figure. Control experiment refers to cells treated with $0.1 \%$ DMSO. Viability was determined as described in Materials and methods. Values represent mean $+/$ - standard deviation from six samples for each treatment condition. (b) M059K whole cell lysates were subjected to Western blot analysis using an antibody against full-length and cleaved PARP. Equal loading was verified by $\beta$-actin detection. (JPEG $42 \mathrm{~kb}$ )

Additional file 4: Figure S4. Western blot analysis of NF-KB protein expression and phosphorylation levels. Whole cell extracts from U-87 MG cells treated with vehicle or $50 \mu M$ D11 for $5 \mathrm{~h}$ and stimulated with $10 \mathrm{ng} / \mathrm{ml}$ TNFa for 10 min prior to harvesting, were analyzed by immunoblotting employing antibodies against NF-kB protein or the phosphorylated form at S536 and S529, respectively. $\beta$-actin detection was used as loading control. (JPEG $26 \mathrm{~kb})$

\section{Competing interests}

The authors declare that they have no competing interests.

\section{Authors' contributions}

BG and OGI conceived the study and its design. BG coordinated the experiments, drafted the manuscript and carried out a large part of the experiments. MF and SS performed part of the cell culture experiments. All authors critically read the final manuscript and approved it.

\section{Acknowledgments}

We thank the Drug Synthesis and Chemistry Branch, Developmental Therapeutics Program, NCl, USA, for providing us with vialed samples. This work was supported by the Danish Council for Independent Research-Natural Sciences (Grant 1323-00212A to B. Guerra).

\section{Author details}

'Department of Biochemistry and Molecular Biology, University of Southern Denmark, Odense, Denmark. ${ }^{2}$ KinaseDetect Aps, Kruså, Denmark.

Received: 29 June 2015 Accepted: 5 October 2015

Published online: 20 October 2015

\section{References}

1. Cancer Genome Atlas Research Network, Kandoth C, Schultz N, Cherniack $A D$, Akbani R, Liu Y, et al. Integrated genomic characterization of endometrial carcinoma. Nature. 2013;497:67-73.

2. Garraway LA. Genomics-driven oncology: framework for an emerging paradigm. J Clin Oncol. 2013;31:1806-14.

3. Herbst RS. Review of epidermal growth factor receptor biology. Int J Radiat Oncol Biol Phys. 2004;59:21-6.

4. Raychaudhuri B, Han Y, Lu T, Vogelbaum MA. Aberrant constitutive activation of nuclear factor kappaB in glioblastoma multiforme drives invasive phenotype. J Neurooncol. 2007:85:39-47.

5. Akimoto T, Hunter NR, Buchmiller L, Mason K, Ang KK, Milas L. Inverse relationship between epidermal growth factor receptor expression and radiocurability of murine carcinomas. Clin Cancer Res. 1999;5:2884-90.

6. Carbone C, Melisi D. NF-kB as a target for pancreatic cancer therapy. Expert Opin Ther Targets. 2012;16 Suppl 2:S1-10.

7. Giralt J, Eraso A, Armengol M, Rosselló J, Majó J, Ares C, et al. Epidermal growth factor receptor is a predictor of tumor response in locally advanced rectal cancer patients treated with preoperative radiotherapy. Int J Radiat Oncol Biol Phys. 2002;54:1460-5.

8. Baumann M, Krause M. Targeting the epidermal growth factor receptor in radiotherapy: radiobiological mechanisms, preclinical and clinical results. Radiother Oncol. 2004;72:257-66.

9. Sun L, Zhang Q, Luan H, Zhan Z, Wang C, Sun B. Comparison of KRAS and EGFR gene status between primary non-small cell lung cancer and local lymph node metastases: implications for clinical practice. J Exp Clin Cancer Res. 2011;30:30.

10. Grana TM, Rusyn EV, Zhou H, Sartor Cl, Cox AD. Ras mediates radioresistance through both phosphatidylinositol 3-kinase-dependent and Raf-dependent but mitogen-activated protein kinase/extracellular signalregulated kinase kinase-independent signaling pathways. Cancer Res. 2002;62:4142-50.

11. Niero EL, Rocha-Sales B, Lauand C, Cortez BA, de Souza MM, Rezende-Teixeira $P$, et al. The multiple facets of drug resistance: one history, different approaches. J Exp Clin Cancer Res. 2014;33:37.

12. Thomas RK, Baker AC, Debiasi RM, Winckler W, Laframboise T, Lin WM, et al. High-throughput oncogene mutation profiling in human cancer. Nat Genet. 2007;39:347-51. 
13. Cancer Genome Atlas Research Network. Comprehensive genomic characterization defines human glioblastoma genes and core pathways. Nature. 2008;455:1061-8.

14. Brennan CW, Verhaak RGW, McKenna A, Campos B, Noushmehr H, Salama SR, et al. The somatic genomic landscape of glioblastoma. Cell. 2013;155:462-77.

15. Cully M, You H, Levine AJ, Mak TW. Beyond PTEN mutations: the PI3K pathway as an integrator of multiple inputs during tumorigenesis. Nat Rev Cancer. 2006;6:184-92.

16. Liu P, Cheng H, Roberts TM, Zhao JJ. Targeting the phosphoinositide 3-kinase pathway in cancer. Nat Rev Drug Discov. 2009:8:627-44.

17. Guerra B, Hochscherf J, Jensen NB, Issinger O-G. Identification of a novel potent, selective and cell permeable inhibitor of protein kinase CK2 from the NIH/NCl Diversity Set Library. Mol Cell Biochem. 2015.

18. Guerra B, Issinger $\mathrm{O}-\mathrm{G}$. Protein kinase CK2 and its role in cellular proliferation, development and pathology. Electrophoresis. 1999;20:391-408.

19. Guerra B, Issinger O-G. Protein kinase CK2 in human diseases. Curr Med Chem. 2008;15:1870-86.

20. Wang D, Westerheide SD, Hanson JL, Baldwin AS. Tumor necrosis factor alpha-induced phosphorylation of RelA/p65 on Ser529 is controlled by casein kinase II. J Biol Chem. 2000;275:32592-7.

21. Torres J, Pulido R. The tumor suppressor PTEN is phosphorylated by the protein kinase CK2 at its C terminus. Implications for PTEN stability to proteasome-mediated degradation. J Biol Chem. 2001;276:993-8.

22. Lin R, Beauparlant P, Makris C, Meloche S, Hiscott J. Phosphorylation of IkappaBalpha in the C-terminal PEST domain by casein kinase II affects intrinsic protein stability. Mol Cell Biol. 1996;16:1401-9.

23. Kato T, Delhase M, Hoffmann A, Karin M. CK2 Is a C-Terminal IkappaB Kinase Responsible for NF-kappaB Activation during the UV Response. Mol Cell. 2003:12:829-39.

24. Olsen BB, Issinger O-G, Guerra B. Regulation of DNA-dependent protein kinase by protein kinase CK2 in human glioblastoma cells. Oncogene. 2010;29:6016-26

25. Allalunis-Turner MJ, Barron GM, Day RS, Dobler KD, Mirzayans R. Isolation of two cell lines from a human malignant glioma specimen differing in sensitivity to radiation and chemotherapeutic drugs. Radiat Res. 1993;134:349-54.

26. Kreutzer JN, Ruzzene M, Guerra B. Enhancing chemosensitivity to gemcitabine via RNA interference targeting the catalytic subunits of protein kinase CK2 in human pancreatic cancer cells. BMC Cancer. 2010;10:440.

27. Chen D, Niu M, Jiao X, Zhang K, Liang J, Zhang D. Inhibition of AKT2 enhances sensitivity to gemcitabine via regulating PUMA and NF-KB signaling pathway in human pancreatic ductal adenocarcinoma. Int J Mol Sci. 2012;13:1186-208.

28. Schmidt M, Hövelmann S, Beckers TL. A novel form of constitutively active farnesylated Akt1 prevents mammary epithelial cells from anoikis and suppresses chemotherapy-induced apoptosis. Br J Cancer. 2002;87:924-32.

29. Yde CW, Olsen BB, Meek D, Watanabe N, Guerra B. The regulatory betasubunit of protein kinase CK2 regulates cell-cycle progression at the onset of mitosis. Oncogene. 2008;27:4986-97.

30. Olsen BB, Wang S-Y, Svenstrup TH, Chen BPC, Guerra B. Protein kinase CK2 localizes to sites of DNA double-strand break regulating the cellular response to DNA damage. BMC Mol Biol. 2012;13:7.

31. Liang C-C, Park AY, Guan J-L. In vitro scratch assay: a convenient and inexpensive method for analysis of cell migration in vitro. Nat Protoc. 2007;2:329-33.

32. Elmore S. Apoptosis: a review of programmed cell death. Toxicol Pathol. 2007:35:495-516.

33. Sebbagh M, Renvoizé C, Hamelin J, Riché N, Bertoglio J, Bréard J. Caspase-3mediated cleavage of ROCK I induces MLC phosphorylation and apoptotic membrane blebbing. Nat Cell Biol. 2001;3:346-52.

34. Coleman ML, Sahai EA, Yeo M, Bosch M, Dewar A, Olson MF. Membrane blebbing during apoptosis results from caspase-mediated activation of ROCK I. Nat Cell Biol. 2001;3:339-45.

35. Mills JC, Stone NL, Pittman RN. Extranuclear apoptosis. The role of the cytoplasm in the execution phase. J Cell Biol. 1999;146:703-8.

36. Shi J, Wu X, Surma M, Vemula S, Zhang L, Yang $Y$, et al. Distinct roles for ROCK1 and ROCK2 in the regulation of cell detachment. Cell Death Dis. 2013:4:e483.

37. Surma M, Handy C, Chang J, Kapur R, Wei L, Shi J. ROCK1 deficiency enhances protective effects of antioxidants against apoptosis and cell detachment. PLoS One. 2014;9:e90758.
38. Cooper JA. Effects of cytochalasin and phalloidin on actin. J Cell Biol. 1987;105:1473-8.

39. Sonkin D, Hassan M, Murphy DJ, Tatarinova TV. Tumor suppressors status in cancer cell line Encyclopedia. Mol Oncol. 2013;7:791-8.

40. Hardie DG, Ross FA, Hawley SA. AMPK: a nutrient and energy sensor that maintains energy homeostasis. Nat Rev Mol Cell Biol. 2012;13:251-62.

41. Inoki K, Zhu T, Guan K-L. TSC2 mediates cellular energy response to control cell growth and survival. Cell. 2003;115:577-90.

42. Gwinn DM, Shackelford DB, Egan DF, Mihaylova MM, Mery A, Vasquez DS, et al. AMPK phosphorylation of raptor mediates a metabolic checkpoint. Mol Cell. 2008;30:214-26.

43. Pratt WB, Toft DO. Regulation of signaling protein function and trafficking by the hsp90/hsp70-based chaperone machinery. Exp Biol Med (Maywood). 2003;228:111-33.

44. Echeverría PC, Bernthaler A, Dupuis P, Mayer B, Picard D. An interaction network predicted from public data as a discovery tool: application to the Hsp90 molecular chaperone machine. PLoS One. 2011;6:e26044.

45. Taipale M, Krykbaeva I, Koeva M, Kayatekin C, Westover KD, Karras Gl, et al. Quantitative analysis of HSP90-client interactions reveals principles of substrate recognition. Cell. 2012;150:987-1001.

46. Fu J, Koul D, Yao J, Wang S, Yuan Y, Colman H, et al. Novel HSP90 inhibitor NVP-HSP990 targets cell-cycle regulators to ablate Olig2-positive glioma tumor-initiating cells. Cancer Res. 2013;73:3062-74.

47. Zuehlke A, Johnson JL. Hsp90 and co-chaperones twist the functions of diverse client proteins. Biopolymers. 2010;93:211-7.

48. Miyata Y. Protein kinase CK2 in health and disease: CK2: the kinase controlling the Hsp90 chaperone machinery. Cell Mol Life Sci. 2009;66:1840-9.

49. Rayet B, Gélinas C. Aberrant rel/nfkb genes and activity in human cancer. Oncogene. 1999;18:6938-47.

50. Hoesel B, Schmid JA. The complexity of NF-kB signaling in inflammation and cancer. Mol Cancer. 2013;12:86.

51. Sun L, Carpenter G. Epidermal growth factor activation of NF-kappaB is mediated through IkappaBalpha degradation and intracellular free calcium. Oncogene. 1998;16:2095-102.

52. Habib AA, Chatterjee S, Park SK, Ratan RR, Lefebvre S, Vartanian T. The epidermal growth factor receptor engages receptor interacting protein and nuclear factor-kappa B (NF-kappa B)-inducing kinase to activate NF-kappa B. Identification of a novel receptor-tyrosine kinase signalosome. J Biol Chem. 2001;276:8865-74.

53. Tanaka K, Babic I, Nathanson D, Akhavan D, Guo D, Gini B, et al. Oncogenic EGFR signaling activates an mTORC2-NF-KB pathway that promotes chemotherapy resistance. Cancer Discov. 2011;1:524-38.

54. Ozes ON, Mayo LD, Gustin JA, Pfeffer SR, Pfeffer LM, Donner DB. NF-kappaB activation by tumour necrosis factor requires the Akt serine-threonine kinase. Nature. 1999:401:82-5.

55. Dan HC, Cooper MJ, Cogswell PC, Duncan JA, Ting JP-Y, Baldwin AS. Aktdependent regulation of NF-\{kappa\}B is controlled by mTOR and Raptor in association with IKK. Genes Dev. 2008;22:1490-500.

56. Ishizaki T, Maekawa M, Fujisawa K, Okawa K, Iwamatsu A, Fujita A, et al. The small GTP-binding protein Rho binds to and activates a $160 \mathrm{kDa}$ Ser/Thr protein kinase homologous to myotonic dystrophy kinase. EMBO J. 1996;15:1885-93.

57. Garzon-Muvdi T, Schiapparelli P, ap Rhys C, Guerrero-Cazares H, Smith C, Kim D-H, et al. Regulation of brain tumor dispersal by NKCC1 through a novel role in focal adhesion regulation. PLoS Biol. 2012;10:e1001320.

58. Fogarty S, Hardie DG. Development of protein kinase activators: AMPK as a target in metabolic disorders and cancer. Biochim Biophys Acta. 1804;2010:581-91.

59. Dutta PR, Maity A. Cellular responses to EGFR inhibitors and their relevance to cancer therapy. Cancer Lett. 2007;254:165-77.

60. Park HU, Suy S, Danner M, Dailey V, Zhang Y, Li H, et al. AMP-activated protein kinase promotes human prostate cancer cell growth and survival. Mol Cancer Ther. 2009;8:733-41.

61. Kahle KT, Rinehart J, Lifton RP. Phosphoregulation of the $\mathrm{Na}-\mathrm{K}-2 \mathrm{Cl}$ and $\mathrm{K}-\mathrm{Cl}$ cotransporters by the WNK kinases. Biochim Biophys Acta. 1802;2010:1150-8.

62. Ríos M, Foretz M, Viollet B, Prieto A, Fraga M, Costoya JA, et al. AMPK activation by oncogenesis is required to maintain cancer cell proliferation in astrocytic tumors. Cancer Res. 2013;73:2628-38.

63. Zhu W, Begum G, Pointer K, Clark PA, Yang S-S, Lin S-H, et al. WNK1-OSR1 kinase-mediated phospho-activation of $\mathrm{Na}+-\mathrm{K}+-2 \mathrm{Cl}$ - cotransporter facilitates glioma migration. Mol Cancer. 2014;13:31. 
64. Fraser SA, Choy S-W, Pastor-Soler NM, Li H, Davies MRP, Cook N, et al. AMPK couples plasma renin to cellular metabolism by phosphorylation of ACC1. Am J Physiol Renal Physiol. 2013;305:F679-90.

65. Viatour P, Merville M-P, Bours V, Chariot A. Phosphorylation of NF-kappaB and IkappaB proteins: implications in cancer and inflammation. Trends Biochem Sci. 2005:30:43-52

66. Friedl $P$, Wolf $K$. Tumour-cell invasion and migration: diversity and escape mechanisms. Nat Rev Cancer. 2003:3:362-74.

67. Bond M, Chase AJ, Baker AH, Newby AC. Inhibition of transcription factor NF-kappaB reduces matrix metalloproteinase-1, -3 and -9 production by vascular smooth muscle cells. Cardiovasc Res. 2001;50:556-65.

68. Simard CF, Daigle ND, Bergeron MJ, Brunet GM, Caron L, Noël M, et al. Characterization of a novel interaction between the secretory $\mathrm{Na}+-\mathrm{K}+-\mathrm{Cl}$ cotransporter and the chaperone hsp90. J Biol Chem. 2004;279:48449-56.

69. Guerra B, Rasmussen TDL, Schnitzler A, Jensen HH, Boldyreff BS, Miyata Y, et al. Protein kinase CK2 inhibition is associated with the destabilization of HIF-1a in human cancer cells. Cancer Lett. 2015;356:751-61.

70. Zhai GG, Malhotra R, Delaney M, Latham D, Nestler U, Zhang M, et al. Radiation enhances the invasive potential of primary glioblastoma cells via activation of the Rho signaling pathway. J Neurooncol. 2006;76:227-37.

\section{Submit your next manuscript to BioMed Central and take full advantage of:}

- Convenient online submission

- Thorough peer review

- No space constraints or color figure charges

- Immediate publication on acceptance

- Inclusion in PubMed, CAS, Scopus and Google Scholar

- Research which is freely available for redistribution 